University of Nebraska - Lincoln

DigitalCommons@University of Nebraska - Lincoln

1995

\title{
The Influence Of Uranyl Hydrolysis And Multiple Site-Binding Reactions On Adsorption Of U(Vi) To Montmorillonite
}

James P. Mckinley

Pacific Northwest National Laboratory

John M. Zachara

Pacific Northwest National Laboratory, john.zachara@pnl.gov

Steven C. Smith

Pacific Northwest National Laboratory

Gary D. Turner

Pacific Northwest National Laboratory

Follow this and additional works at: https://digitalcommons.unl.edu/usdoepub

Part of the Bioresource and Agricultural Engineering Commons

Mckinley, James P.; Zachara, John M.; Smith, Steven C.; and Turner, Gary D., "The Influence Of Uranyl Hydrolysis And Multiple Site-Binding Reactions On Adsorption Of U(Vi) To Montmorillonite" (1995). US Department of Energy Publications. 193.

https://digitalcommons.unl.edu/usdoepub/193

This Article is brought to you for free and open access by the U.S. Department of Energy at DigitalCommons@University of Nebraska - Lincoln. It has been accepted for inclusion in US Department of Energy Publications by an authorized administrator of DigitalCommons@University of Nebraska - Lincoln. 


\title{
THE INFLUENCE OF URANYL HYDROLYSIS AND MULTIPLE SITE-BINDING REACTIONS ON ADSORPTION OF U(VI) TO MONTMORILLONITE
}

\author{
James P. McKinley, John M. Zachara, Steven C. Smith, and Gary D. Turner \\ Pacific Northwest Laboratory, MSIN K3-61, P.O. Box 999, Richland, Washington 99352
}

\begin{abstract}
Adsorption of uranyl to SWy-1 montmorillonite was evaluated experimentally and results were modeled to identify likely surface complexation reactions responsible for removal of uranyl from solution. Uranyl was contacted with SWy-1 montmorillonite in a $\mathrm{NaClO}_{4}$ electrolyte solution at three ionic strengths $(\mathrm{I}=0.001,0.01,0.1)$, at $\mathrm{pH} 4$ to 8.5 , in a $\mathrm{N}_{2(\mathrm{~g})}$ atmosphere. At low ionic strength, adsorption decreased from $95 \%$ at $\mathrm{pH} 4$ to $75 \%$ at $\mathrm{pH} 6.8$. At higher ionic strength, adsorption increased with $\mathrm{pH}$ from initial values less than 75\%; adsorption edges for all ionic strengths coalesced above a $\mathrm{pH}$ of 7 . A site-binding model was applied that treated SWy-1 as an aggregate of fixed-charge sites and edge sites analogous to gibbsite and silica. The concentration of fixed-charge sites was estimated as the cation exchange capacity, and non-preference exchange was assumed in calculating the contribution of fixed-charge sites to total uranyl adsorption. The concentration of edge sites was estimated by image analysis of transmission electron photomicrographs. Adsorption constants for uranyl binding to gibbsite and silica were determined by fitting to experimental data, and these adsorption constants were then used to simulate SWy-1 adsorption results. The best simulations were obtained with an ionization model in which $\mathrm{AlOH}_{2}{ }^{+}$was the dominant aluminol surface species throughout the experimental range in $\mathrm{pH}$. The $\mathrm{pH}$-dependent aqueous speciation of uranyl was an important factor determining the magnitude of uranyl adsorption. At low ionic strength and low $\mathrm{pH}$, adsorption by fixed-charge sites was predominant. The decrease in adsorption with increasing $\mathrm{pH}$ was caused by the formation of monovalent aqueous uranyl species, which were weakly bound to fixed-charge sites. At higher ionic strengths, competition with $\mathrm{Na}^{+}$decreased the adsorption of $\mathrm{UO}_{2}{ }^{2+}$ to fixed-charge sites. At higher $\mathrm{pH}$, the most significant adsorption reactions were the binding of $\mathrm{UO}_{2}{ }^{2+}$ to $\mathrm{AlOH}$ and of $\left(\mathrm{UO}_{2}\right)_{3}(\mathrm{OH})_{5}{ }^{+}$to SiOH edge sites. Near-saturation of AlOH sites by $\mathrm{UO}_{2}{ }^{2+}$ allowed significant contributions of $\mathrm{SiOH}$ sites to uranyl adsorption.
\end{abstract}

Key Words-Montmorillonite, Uranyl.

\section{INTRODUCTION}

Uranium is a widespread environmental contaminant resulting from mining and manufacturing activities related to nuclear power and weapons production. At U.S. Department of Energy facilities, for example, uranium is the most common radionuclide contaminant in groundwater/sediment systems (Riley et al 1992). The mobility of uranium is enhanced in oxidizing environments by the formation of uranyl $\left(\mathrm{UO}_{2}{ }^{2+}\right)$, which hydrolyzes to form a number of aqueous hydroxy species. The hydrolysis reactions considered here and their equilibrium constants (Grenthe 1992) are listed in Table 1; computed aqueous speciation of $\mathrm{UO}_{2}{ }^{2+}$ at I $=0.1$, over $\mathrm{pH}$ of 4 to 9 is illustrated in Figure 1.

In near-surface groundwater systems, chemical interactions with solid surfaces act to retard uranyl mobility. The adsorption of uranyl ion to solid substances has been studied as a mobility-limiting process, particularly with respect to sorption by $\mathrm{Fe}$ oxides (Payne and Waite 1991, Hsi and Langmuir 1985, Ho and Miller 1985, Tripathi 1984, Maya 1982) and phyllosilicate minerals (Borovec 1981, Tsunashima et al 1981, Lieser et al 1992). In addition to constraining the mobility of contaminant uranium associated with mine tailings sites
(Bonotto 1989, Thomson et al 1986, Morin et al 1982, Morin and Cherry 1988), sorption reactions are thought to be an important component of the formation of economic uranium deposits (Fiala 1988, Giblin 1980). Quantitative modeling of uranyl adsorption to natural substrates has been limited to oxides and oxyhydroxides (e.g., Hsi and Langmuir 1985, Payne and Waite 1991); iron oxyhydroxides in particular have been studied because they have high adsorption capacity and are common accessory minerals or coatings in sediments and soils where uranyl adsorption reactions are significant. Iron oxyhydroxides are, however, only a small subset of the reactive constituents found in soils and sediments.

In this study we investigate the adsorption of uranyl to Wyoming montmorillonite $\mathrm{SWy}-1$, a well-studied reference smectite. Smectites are ubiquitous 2:1 sheet silicates found as clay-sized components of soils and sediments, consisting of octahedrally coordinated aluminum atoms sandwiched between tetrahedrally coordinated silicon atoms. Cation substitutions within the crystal lattice can occur in either the octahedral $\left(\mathrm{Mg}^{2+}\right.$ for $\left.\mathrm{Al}^{3+}\right)$ or tetrahedral $\left(\mathrm{Al}^{3+}\right.$ for $\left.\mathrm{Si}^{4+}\right)$ sheets, resulting in a fixed negative charge that dominates the mineral's cation exchange capacity (CEC). Partially coordinated $\mathrm{Al}$ and $\mathrm{Si}$ are exposed at crystallite edges, 
Table 1. Equilibrium constants.

\begin{tabular}{|c|c|}
\hline Reaction & $\log K$ \\
\hline $\begin{array}{l}\text { Aqueous speciation } \\
\mathrm{UO}_{2}{ }^{2+}+\mathrm{H}_{2} \mathrm{O}=\mathrm{UO}_{2}(\mathrm{OH})^{+}+\mathrm{H}^{+} \\
2 \mathrm{UO}_{2}{ }^{2+}+2 \mathrm{H}_{2} \mathrm{O}=\left(\mathrm{UO}_{2}\right)_{2}(\mathrm{OH})_{2}{ }^{2+}+2 \mathrm{H}^{+} \\
3 \mathrm{UO}_{2}^{2+}+5 \mathrm{H}_{2} \mathrm{O}=\left(\mathrm{UO}_{2}\right)_{3}(\mathrm{OH})_{5}++5 \mathrm{H}^{+} \\
\mathrm{UO}_{2}{ }^{2+}+3 \mathrm{H}_{2} \mathrm{O}=\mathrm{UO}_{2}(\mathrm{OH})_{3}{ }^{-}+3 \mathrm{H}^{+}\end{array}$ & $\begin{array}{l}-5.20^{1} \\
-5.62^{1} \\
-15.55^{1} \\
-21.0^{1}\end{array}$ \\
\hline \multicolumn{2}{|l|}{ Ion exchange reactions } \\
\hline $\begin{array}{l}\mathrm{UO}_{2}{ }^{2+}+2 \mathrm{X}^{-}=\mathrm{UO}_{2} \mathrm{X}_{2} \\
\mathrm{UO}_{2}(\mathrm{OH})^{+}+\mathrm{X}^{-}=\mathrm{UO}_{2}(\mathrm{OH}) \mathrm{X} \\
\left(\mathrm{UO}_{2}\right)_{3}(\mathrm{OH})_{5}{ }^{+}+\mathrm{X}^{-}=\left(\mathrm{UO}_{2}\right)_{3}(\mathrm{OH})_{5} \mathrm{X}\end{array}$ & $\begin{array}{l}30.9^{2,3} \\
8.6^{3} \\
-1.75^{3}\end{array}$ \\
\hline \multicolumn{2}{|l|}{ Edge-site reactions } \\
\hline $\begin{array}{l}\mathrm{SiOH}+\mathrm{H}^{+}=\mathrm{SiOH}_{2}^{+} \\
\mathrm{SiOH}=\mathrm{SiO}^{-}+\mathrm{H}^{+} \\
\mathrm{SiOH}+\mathrm{Na}^{+}=\mathrm{SiO}^{-}-\mathrm{Na}^{+}+\mathrm{H}^{+} \\
\mathrm{SiOH}+\mathrm{UO}_{2}^{2+}=\mathrm{SiO} \cdot \mathrm{UO}_{2}^{+}+\mathrm{H}^{+} \\
\mathrm{SiOH}+\left(\mathrm{UO}_{2}\right)_{3}(\mathrm{OH})_{5}^{+}=\mathrm{SiO} \cdot\left(\mathrm{UO}_{2}\right)_{3}(\mathrm{OH})_{5}+\mathrm{H}^{+}\end{array}$ & $\begin{array}{l}-0.95^{4} \\
-6.95^{4} \\
-6.6^{4} \\
0.146^{5} \\
-16.80^{5}\end{array}$ \\
\hline $\begin{array}{l}\mathrm{AlOH}+\mathrm{H}^{+}=\mathrm{AlOH}_{2}^{+} \\
\mathrm{AlOH}=\mathrm{AlO}^{-}+\mathrm{H}^{+} \\
\mathrm{AlOH}+\mathrm{Na}^{+}=\mathrm{AlO}^{-}-\mathrm{Na}^{+}+\mathrm{H}^{+} \\
\mathrm{AlOH}+\mathrm{UO}_{2}^{2+}=\mathrm{AlO} \cdot \mathrm{UO}_{2}^{+}+\mathrm{H}^{+} \\
\mathrm{AlOH}+\left(\mathrm{UO}_{2}\right)_{3}(\mathrm{OH})_{5}{ }^{+}=\mathrm{AlO} \cdot\left(\mathrm{UO}_{2}\right)_{3}(\mathrm{OH})_{5}+\mathrm{H}^{+}\end{array}$ & $\begin{array}{r}12.3^{5} \\
-13.6^{5} \\
-10.37^{5} \\
7.10^{5} \\
-15.8^{5}\end{array}$ \\
\hline
\end{tabular}

1 Grenthe, 1992.

${ }^{2}$ Fixed relative to $\mathrm{Na}^{+}$constant.

${ }^{3}$ Calculated as explained in the text.

${ }^{4}$ Zachara and Smith 1994.

${ }^{5}$ This study, Model 1.

which hydrolyze to form aluminol (AlOH) and silanol (SiOH) groups (White and Zelazny 1988). These hydroxylated sites exhibit acid/base behavior and coordinative properties analogous to those of their component oxides [i.e., $\mathrm{SiO}_{2}, \mathrm{Al}(\mathrm{OH})_{3}$ ]; recent experimental and modeling studies have attempted to quantify the contributions of edge sites to metal ion retention by smectites and other layer silicates (Fletcher and Sposito 1989, Zachara et al 1993, Stadler and Schindler 1993, Zachara and Smith 1994).

The use of surface-site concentrations, surface-binding reactions, and adsorption constants as fitting parameters in adsorption modeling can lead to successful but underconstrained models of experimental systems. The studies of Hsi and Langmuir (1985) and Payne and Waite (1991), for example, each described uranyl adsorption to iron oxyhydroxides by trial and error fitting of the experimental data, but the surface-binding reactions and constants used did not agree between the two studies; the limitations of this approach were recognized in the latter study.

The system studied here included a heterogeneous suite of surface sites and multiple aqueous species that could potentially bind at the solid surface; the abundance of adjustable parameters in this system could lead to a poorly constrained chemical model. Our objective was to construct a chemical model of uranyl/ smectite interactions with a minimum number of parameters, using measurements of site concentrations

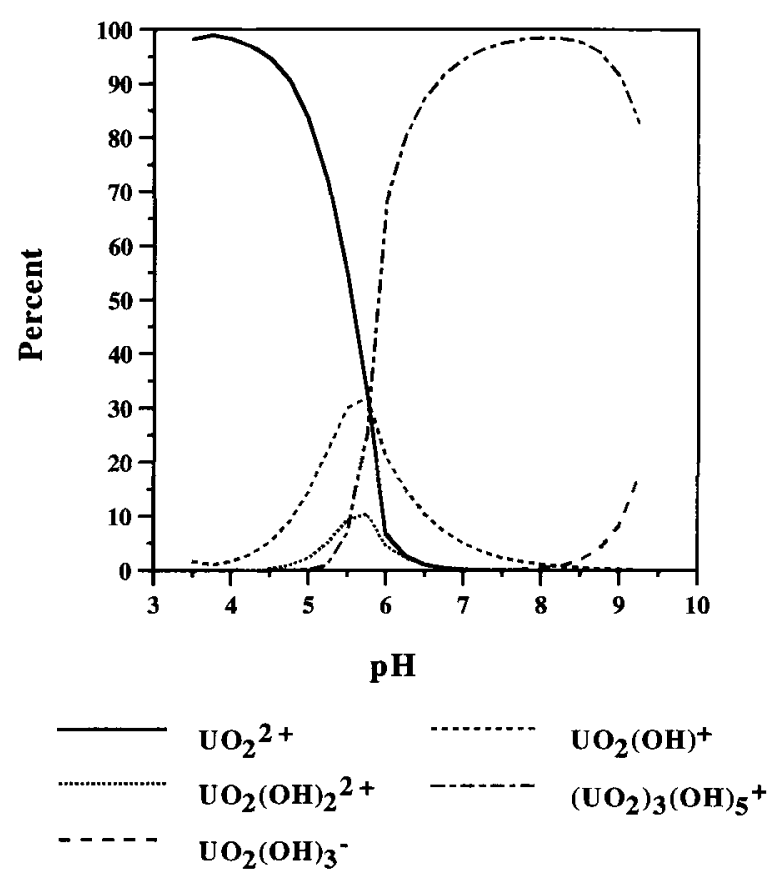

Figure 1. Uranyl speciation at varying $\mathrm{pH}$. Calculations are for $8 \times 10^{-6} \mathrm{~mol} \mathrm{~L}^{-1}$ uranyl in solution of ionic strength 0.1 . Speciation constants from Grenthe (1992). 
and adsorption constants that were independent of the experimental smectite adsorption data. A multiple-site adsorption model containing fixed-charge $\left(\mathrm{X}^{-}\right)$and hydroxylated edge sites $(\mathrm{AlOH}, \mathrm{SiOH})$, similar to those developed by Schindler et al (1987) for kaolinite, and by Stadler and Schindler (1993) for SWy-1, was used to compute aqueous speciation and uranyl adsorption to surface sites. We have applied assumptions of likely surface reactions on the analogue solids, silica and gibbsite, to derive adsorption constants describing binding reactions to comparable sites on the edge of the clay. Although the identity of responsible surface chemical reactions cannot be determined definitively through macroscopic modeling, our approach constrains the model to a greater degree than would direct parameter fitting.

\section{MATERIALS AND METHODS}

\section{Sorbent preparation}

The less than $2-\mu \mathrm{m}$ size fraction of SWy-1 was separated from the bulk material and pretreated with 0.001 $\mathrm{N} \mathrm{HClO}_{4}$ to remove surface precipitates, with $3 \%$ hydrogen peroxide $\left(\mathrm{H}_{2} \mathrm{O}_{2}\right)$ to remove organic matter, and washed repeatedly with $0.1 \mathrm{~mol} \mathrm{~L}^{-1} \mathrm{NaClO}_{4}$. The resultant stock suspension was stored under ultraviolet light to suppress microbial activity. The proportions of clay, salt, and $\mathrm{H}_{2} \mathrm{O}$ in the suspensions were determined according to the procedure described by Sposito et al (1981).

Gibbsite $\left[\mathrm{Al}(\mathrm{OH})_{3}, \mathrm{ALCAN} \mathrm{SF-4,} \mathrm{Alcoa]} \mathrm{was} \mathrm{pre-}\right.$ treated by first shaking a suspension of $5 \mathrm{~g}$ of gibbsite in $20 \mathrm{ml}$ of $0.01 \mathrm{~N} \mathrm{NaOH}$ for $30 \mathrm{~min}$, followed immediately by seven successive washes with $0.01 \mathrm{~mol}$ $\mathrm{L}^{-1} \mathrm{NaClO}_{4}$. Silica ( $\mathrm{SiO}_{2}$, Aerosil 200, Degussa, Inc.) was placed in suspension at the desired density and equilibrated by shaking overnight.

\section{Chemical and physical measurements}

The external surface area of the solid reactants was measured by multipoint $\mathrm{N}_{2}$ adsorption. Particle sizes, used to calculate smectite surface areas and edge-site concentrations for modeling purposes, were determined using a Phillips 300 transmission electron microscope (TEM). Smectite particles from dilute suspensions were affixed to carbon-coated copper grids. Grids were examined at high magnification to select the optimum resultant particle spacing (i.e., a high particle density with a minimal number of overlapping particles). Several such observation fields were photographed. The images were digitized, particle overlaps were removed by editing the digital image (less than $5 \%$ of the total number of grains overlapped), and the mean particle size and equivalent particle diameter (the diameter of a circle with equivalent area) were calculated using image acquisition and processing software. Over 200 particles were analyzed by this process.
Acid-base titration of gibbsite was done by a batch method, in which replicate suspensions of gibbsite were equilibrated with known masses of added acid and base. Gibbsite suspensions were prepared at a massto-liquid ratio of $90 \mathrm{~g} \mathrm{~L}^{-1}\left(300 \mathrm{~m}^{2} \mathrm{~L}^{-1}\right)$ and equilibrated over a pH range of 4.5 to 9.5 using carbonatefree $\mathrm{NaOH}$ and $\mathrm{HClO}_{4}$. After measurement of equilibrium $\mathrm{pH}$ values, suspension aliquots were filtered through 1.8-nm cone filters, and the filtrate was acidified with ultrapure $\mathrm{HCl}$ and analyzed for dissolved aluminum using an inductively coupled plasma-mass spectrometry system (with a detection limit of $0.1 \mathrm{ng}$ $\mathrm{ml}^{-1}$ ) to determine the mass of gibbsite dissolved during the titration. Blank titration data were collected and modelled using FITEQL (Westall 1982a,b, 1993), and experimental data were corrected for aqueous protolysis effects using the results of that modeling.

Isotopic exchange ( ${ }^{22} \mathrm{Na}$; Babcock and Schultz 1970) was used to determine the CEC of the sorbent over the $\mathrm{pH}$ range from 4.0 to 8.0 in the presence of 0.01 and $0.1 \mathrm{~mol} \mathrm{~L}^{-1} \mathrm{NaClO}_{4}$. Suspensions of the $\mathrm{Na}^{+}$-saturated sorbent materials were equilibrated for $24 \mathrm{~h}$ after $\mathrm{pH}$ adjustment with $\mathrm{NaOH}$ or $\mathrm{HClO}_{4}$. Following an additional 14-h equilibration period in the presence of ${ }^{22} \mathrm{Na}^{+}$, the suspensions were centrifuged at 30,000 rcf for $30 \mathrm{~min}$; then supernatant ${ }^{22} \mathrm{Na}^{+}$activity (scintillation counting), $\mathrm{Na}^{+}$concentration (ion chromatography), and $\mathrm{pH}$ were determined.

Bulk chemical composition of SWy-1 was determined on a sodium-saturated sample that was dialyzed before freeze-drying to remove excess salt. Clay powder $(500 \mathrm{mg})$ was pressed into a wafer for X-ray fluorescence determination of $\mathrm{Al}, \mathrm{Si}, \mathrm{K}, \mathrm{Ti}, \mathrm{Mn}$, and Fe. The clay $\left(50 \mathrm{mg}\right.$ ) was mixed with $600 \mathrm{mg} \mathrm{LiBO}_{2}$, fused at $900{ }^{\circ} \mathrm{C}$, and dissolved in dilute $\mathrm{HNO}_{3}$ for determination of $\mathrm{Na}$ and $\mathrm{Mg}$ by atomic absorption spectroscopy. Gravimetric moisture content was determined after heating the clay to $105^{\circ} \mathrm{C}$ and again after heating it to $900^{\circ} \mathrm{C}$.

\section{Adsorption experiments}

Adsorption experiments were conducted under $\mathbf{N}_{2(\mathrm{~g})}$ to preclude the complexation of uranyl by dissolved carbonate. Experimental conditions are summarized in Table 2. Suspensions were prepared using degassed electrolyte solutions diluted with deionized water to compositions of $0.001 \mathrm{~mol} \mathrm{~L}^{-1}$ to $0.100 \mathrm{~mol} \mathrm{~L}^{-1}$ $\mathrm{NaClO}_{4}$. A mass of stock clay suspension containing the desired mass of SWy-1 was transferred to a centrifuge tube and washed three times in the electrolyte solution. The total mass of $\mathrm{SWy}-1$ suspension, placed in a jacketed $500-\mathrm{ml}$ reaction vessel, was adjusted to yield a final suspension charge concentration of 0.5 meq $\mathrm{kg}^{-1}$, based on the measured CEC at $\mathrm{pH}$ 6. An autotitrator was used to monitor and adjust $\mathrm{pH}$ using 0.01 mol L-1 $\mathrm{NaOH}$ or $\mathrm{HClO}_{4}$. A glass $\mathrm{pH}$ electrode and calomel reference electrode (isolated from the sus- 
Table 2. Experimental conditions for uranyl adsorption to SWy-1, gibbsite, and $\mathrm{SiO}_{2}$.

\begin{tabular}{llccccc}
\hline Sorbent & $\begin{array}{c}\text { Susp. } \\
\left(\mathrm{g} \mathrm{kg}^{-1}\right)\end{array}$ & $\begin{array}{c}\mathbf{S . A} . \\
\left(\mathbf{m}^{\mathbf{2}} \mathbf{g}^{-1}\right)\end{array}$ & $\begin{array}{c}\mathrm{SiOH} \\
(\mu \mathrm{mol} \\
\left.\mathrm{L}^{-1}\right)\end{array}$ & $\begin{array}{c}\mathrm{AlOH} \\
(\mu \mathrm{mol} \\
\left.\mathbf{L}^{-1}\right)\end{array}$ & $\begin{array}{c}\mathrm{U} \\
(\mu \mathrm{mol} \\
\left.\mathbf{L}^{-1}\right)\end{array}$ & $\begin{array}{c}\mathrm{Na} \\
\left(\begin{array}{c}\mathrm{mmol} \\
\left.\mathbf{L}^{-1}\right)\end{array}\right.\end{array}$ \\
\hline SWy-1 & 0.59 & 31 & 11 & 9.9 & 8.7 & 96 \\
& 0.59 & & 11 & 9.9 & 8.5 & 9.7 \\
$\mathrm{SiO}_{2}$ & 0.59 & & 11 & 9.9 & 8.6 & 4.0 \\
& 0.13 & 180 & 18 & & 9.0 & 91 \\
& 0.15 & & 21 & & 9.4 & 9.1 \\
Gibbsite & 0.013 & & 1.8 & & 8.9 & 97 \\
& 5.6 & 3.4 & & 19 & 9.1 & 1.2 \\
& 5.7 & & & 19 & 9.3 & 95 \\
& 0.55 & & & 1.9 & 9.1 & 98 \\
\hline
\end{tabular}

pension by an agar bridge) were used to minimize contamination of the suspension by $\mathrm{KCl}$. The stirred suspension was allowed to equilibrate at $\mathrm{pH} 4.0$ for $16 \mathrm{~h}$ before adding uranyl.

A uranyl nitrate $\left[\mathrm{UO}_{2}\left(\mathrm{NO}_{3}\right)_{2} \cdot 6 \mathrm{H}_{2} \mathrm{O}\right.$; Fluka Chemical Co., greater than $99.0 \%$ purity] stock solution containing $195 \mathrm{mg} \mathrm{U} \mathrm{kg}^{-1}$ was added by mass to the equilibrated SWy-1 suspensions to yield an initial $U$ concentration of $2 \mathrm{mg} \mathrm{L}^{-1}\left(8.4 \times 10^{-6} \mathrm{~mol} \mathrm{~L}^{-1}\right)$. The $\mathrm{pH}$ of the suspension was increased incrementally by addition of $\mathrm{NaOH}$, and duplicate $15-\mathrm{ml}$ samples were removed at each 0.5 -pH-unit step. The samples were equilibrated for $20 \mathrm{~h}$ in a controlled-environment shaker $\left(150 \mathrm{rpm}, 25^{\circ} \mathrm{C}\right)$. The equilibrated samples were centrifuged at 5,000 $\mathrm{rcf}$ for $1 \mathrm{~h}$, and separate $4-\mathrm{ml}$ samples of the supernatant were removed for determination of $\mathrm{pH}$, solution-phase uranyl concentration, and $\mathrm{Na}$ concentration. The final $\mathrm{pH}$ of the supernatant was measured under a $\mathrm{N}_{2}$ atmosphere using a combination electrode. The quantity of uranyl adsorbed was calculated from the difference between initial and final solutionphase uranyl concentrations. Uranium concentration was determined using a kinetic phosphorescence analyzer (Model KPA-11, CHEMCHEK Instruments, Inc.); the detection limit for these analyses was $0.3 \mu \mathrm{g}$ $\mathrm{U} \mathrm{L}^{-1}$, with an analytical precision of $0.09 \mu \mathrm{g} \mathrm{U} \mathrm{L}^{-1}$. These limits compare to a range in experimental samples of 3 to $2,000 \mu \mathrm{g} \mathrm{U} \mathrm{L} ~^{-1}$.

The adsorption behavior of uranyl on gibbsite and silica was determined using an experimental approach identical to that described above for uranyl adsorption to SWy-1. Two suspension concentrations, differing by approximately one order of magnitude for each adsorbent (described below), were used to determine the extent of adsorption under conditions of different aqueous uranyl speciation.

\section{RESULTS}

\section{Chemical and physical properties}

The elemental analysis (Table 3 ), reduced using the method of Newman and Brown (1987), yielded a 2:1 clay-mineral structural formula of $\left(\mathrm{Ca}_{0.001} \mathrm{Na}_{0.707^{-}}\right.$
Table 3. Physical and chemical properties of Na-saturated SWy-1 montmorillonite.

\begin{tabular}{|c|c|}
\hline \multicolumn{2}{|l|}{ Composition: } \\
\hline $\mathrm{SiO}_{2}$, wt. $\%$ & 61.6 \\
\hline $\mathrm{Al}_{2} \mathrm{O}_{3}$ & 21.2 \\
\hline $\mathrm{Fe}_{2} \mathrm{O}_{3}$ & 4.29 \\
\hline $\mathrm{TiO}_{2}$ & 0.08 \\
\hline $\mathrm{MnO}$ & 0.03 \\
\hline $\mathrm{MgO}$ & 2.80 \\
\hline $\mathrm{CaO}$ & 0.01 \\
\hline $\mathrm{Na}_{2} \mathrm{O}$ & 2.86 \\
\hline $\mathrm{K}_{2} \mathrm{O}$ & 0.02 \\
\hline $\mathrm{H}_{2} \mathrm{O}$ & 7.1 \\
\hline Total & $\overline{99.96}$ \\
\hline
\end{tabular}

Mean equivalent particle diameter: $0.48 \mu \mathrm{m}$ Surface area: $31 \mathrm{~m}^{2} \mathrm{~g}^{-1}$

$\left.\mathrm{K}_{0.003}\right)\left[\mathrm{Al}^{3.04} \mathrm{Fe}(\mathrm{III})_{0.41} \mathrm{Mg}_{0.532}\right]\left(\mathrm{Si}_{7.85} \mathrm{Al}_{0.147}\right) \mathrm{O}_{20} \mathrm{OH}_{4}$ (montmorillonite).

The CEC of Swy-1 shows a relatively small dependence on $\mathrm{pH}$ and ionic strength (Figure 2); $\mathrm{CEC}$ at pH 4 is $0.63 \mathrm{mmol}_{\mathrm{c}} \mathrm{g}^{-1}$; CEC at $\mathrm{pH} 10$ is $0.75 \mathrm{mmol}_{\mathrm{c}} \mathrm{g}^{-1}$. Changes in CEC with pH result from the additive contribution of fixed-charge and ionized edge sites; i.e., SiOH and AlOH (White and Zelazny 1988; Sposito 1989). The dissolution and readsorption of $\mathrm{Al}^{3+}$ at lower $\mathrm{pH}$ may also contribute to this trend in CEC. A calculation based on composition and unit cell parameters (Newman 1987) gives a fixed charge ( $\mathrm{pH}$-independent CEC) of $0.95 \mathrm{mmol}_{c} \mathrm{~g}^{-1}$ arising from interlayer cation charge. Our measurement gives $0.74 \mathrm{mmol}_{c} \mathrm{~g}^{-1}$ in $0.01 \mathrm{~mol} \mathrm{~L}^{-1}$ to $0.1 \mathrm{~mol} \mathrm{~L}^{-1} \mathrm{NaClO}_{4}$ at $\mathrm{pH} 6.0$; this value was used as the unit-mass concentration of fixedcharge sites in model calculations. The discrepancy between theoretical and experimental determinations of $\mathrm{CEC}$ is unexplained.

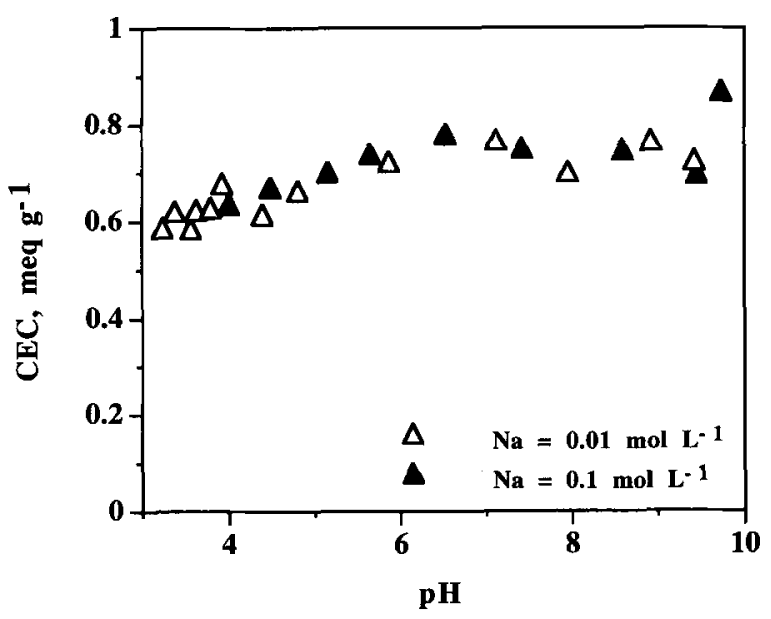

Figure 2. Cation exchange capacity of treated SWy-1 at varying $\mathrm{pH}$ and two ionic strengths. 
a. Gibbsite $5.74 \mathrm{~g} \mathrm{~L}^{-1}$

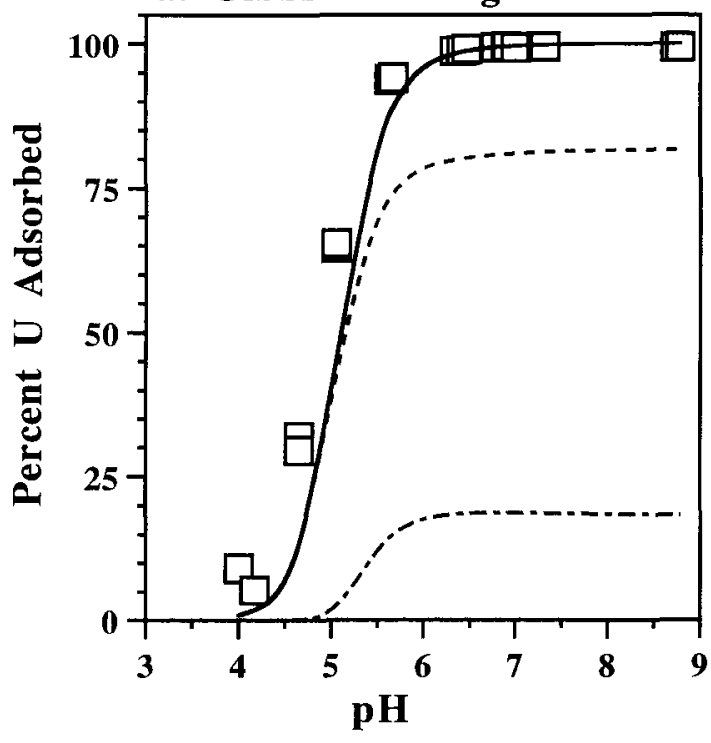

c. Silica $0.134 \mathrm{~g} \mathbf{L}^{-1}$

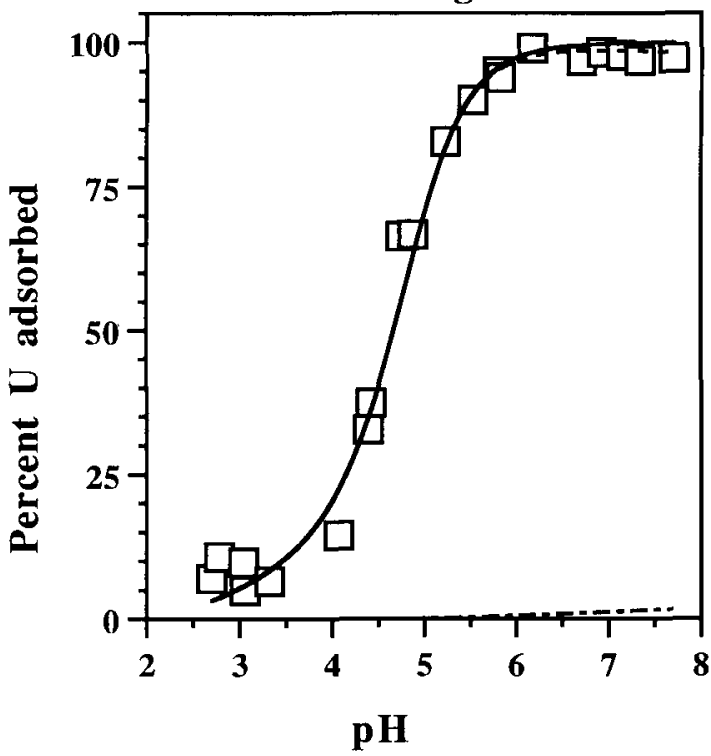

b. Gibbsite $0.55 \mathrm{~g} \mathrm{~L}^{-1}$

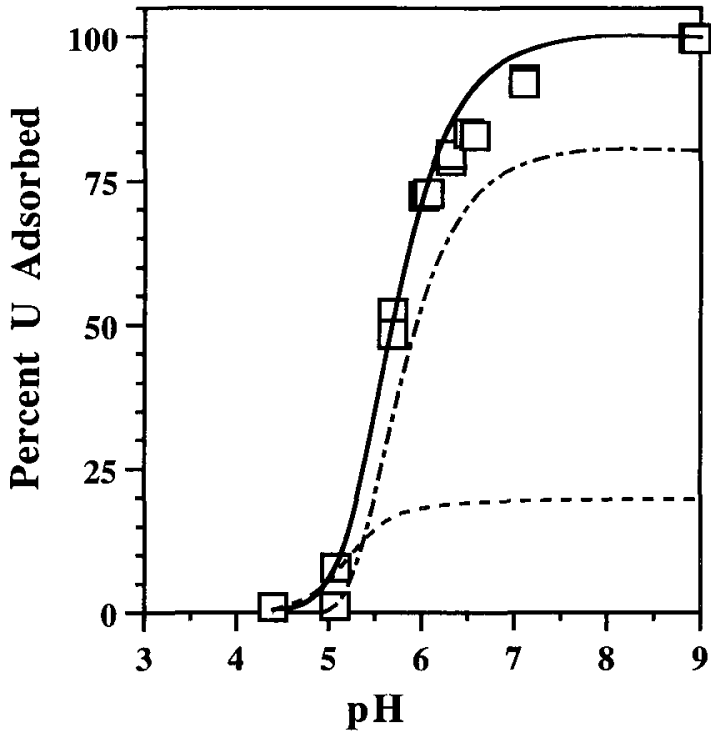

d. Silica $0.0128 \mathrm{~g} \mathrm{~L}^{-1}$

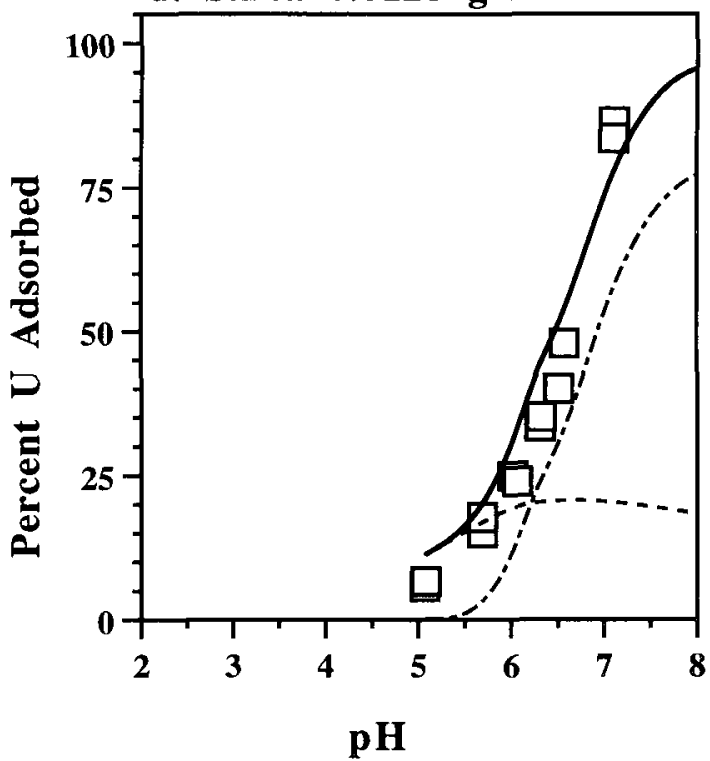

Figure 3. Experimental results of uranyl interaction with gibbsite $(a, b)$ and silica (c,d). Total computed contributions to adsorption $=$ solid line; monomeric $\left(\mathrm{UO}_{2}{ }^{2+}\right)$ surface complex $=$ dashed line; trimeric $\left[\left(\mathrm{UO}_{2}\right)_{3}(\mathrm{OH})_{5}{ }^{+}\right]$surface complex $=$dotdashed line.

\section{Adsorption experiments}

Suspension concentrations of gibbsite and silica at higher solid-to-solution ratios (Table 2) were sufficient to produce greater than $50 \%$ adsorption of uranyl below a pH of 5.2 (Figure 3 ), where $\mathrm{UO}_{2}{ }^{2+}$ predominated in solution (Figure 1). Experiments at a solids concentration of one-tenth the higher value had lower adsorption at equivalent $\mathrm{pH}$; i.e., the adsorption edge was shifted to higher $\mathrm{pH}$ where multiple, hydrolyzed uranyl species existed. In an investigation of uranyl adsorption to silica gel $\left(\mathrm{SiO}_{2} \cdot \mathrm{xH}_{2} \mathrm{O}\right)$, Lieser et al (1992) found an adsorption maximum at approximately pH 6.7. Data from Allard et al (1983) were calculated by Lieser et al (1992) to yield similar results for $\mathrm{Al}_{2} \mathrm{O}_{3}$. Lieser et al (1992) concluded that decreased adsorption at elevated $\mathrm{pH}$, similar for differing adsorbents, showed the effects of changes in aqueous uranyl speciation toward pre- 
dominance of an anionic species $\left.\left[\left(\mathrm{UO}_{2}\right)_{3}(\mathrm{OH})_{7}{ }^{-}\right)\right]$. In contrast, our experiments showed a continued increase in adsorption at $\mathrm{pH}$ above 6.7 , suggesting that the formation of an anionic species was not a significant determinant of overall adsorption results.

The adsorption of uranyl by SWy-l varied with $\mathrm{pH}$ and ionic strength (Figure 4). Adsorption was most dependent on ionic strength at low $\mathrm{pH}$, with adsorption edges coalescing at all ionic strengths above $\mathrm{pH}$ 6.5. This behavior may result from adsorption to two classes of sites on the solid surface: fixed-charge sites sensitive to competitive exchange between sodium and uranyl ions, and edge sites to which uranyl is specifically adsorbed without significant competition from sodium.

Hydrolysis of $\mathrm{UO}_{2}{ }^{2+}$ may also affect adsorption. (In the remainder of the text, we use "uranyl" to refer to $\mathrm{UO}_{2}{ }^{2+}$ and its hydrolysis products without differentiation, and restrict the use of " $\mathrm{UO}_{2}{ }^{2+}$ " to mean unhydrolyzed uranyl ion.). At low ionic strength, for example (Figure 4), the fractional adsorption of uranyl decreased over the $\mathrm{pH}$ range of 4 to 6.5. This decrease was paralleled by a reduction in the aqueous concentration of $\mathrm{UO}_{2}{ }^{2+}$ in favor of $\mathrm{UO}_{2}(\mathrm{OH})^{+}$and $\left(\mathrm{UO}_{2}\right)_{3}(\mathrm{OH})_{5}{ }^{+}$(Figure 1). One may speculate that ion exchange was the predominant adsorption mechanism for uranyl over this $\mathrm{pH}$ range, and that the divalent $\mathrm{UO}_{2}{ }^{2+}$ ion competed with $\mathrm{Na}^{+}$more effectively than did the monovalent uranyl hydroxide ion $\left[\mathrm{UO}_{2}(\mathrm{OH})^{+}\right]$. This hypothesis parallels the exchange reaction modelled by Stadler and Schindler (1993) with respect to copper adsorption to $\mathrm{SWy}-1$. At slightly alkaline $\mathrm{pH}$, copper forms a single hydrolyzed species that is analogous to $\mathrm{UO}_{2}(\mathrm{OH})^{+}\left(\mathrm{CuOH}^{+} ; \mathrm{Log} \mathrm{K}=-8.29\right)$; in nonpreference exchange neither monovalent species is significantly removed from solution in the presence of excess $\mathrm{Na}^{+}$. In contrast, the ion exchange of weakly hydrolyzing divalent metals, such as $\mathrm{Cd}^{2+}$, which does not form a monovalent complex over the $\mathrm{pH}$ range of interest, does not decrease with increasing $\mathrm{pH}$ unless other competitive sites, sorbents, or ligands exist (Zachara et al 1993, Zachara and Smith 1994).

\section{ADSORPTION MODELING}

The smectite surface was considered to consist of three discrete sites: fixed-charge ion-exchange sites $\left(\mathrm{X}^{-}\right)$ on the smectite basal plane, and hydroxylated $\mathrm{SiOH}$ and $\mathrm{AlOH}$ edge sites. The chemical modeling program FITEQL (Westall 1982a, b) was used to compute the contribution of each site to adsorption using the TripleLayer Model (TLM, Davis and Leckie 1978, Sposito 1984, Hayes and Leckie 1987) for the amphoteric edge sites, and a half-reaction approach was used (Fletcher and Sposito 1989) for the fixed-charge sites. The integral capacitance densities, $\mathrm{C}_{1}$ and $\mathrm{C}_{2}$, were fixed at 1.2 and $0.20 \mathrm{~F} \mathrm{~m}^{-2}$, respectively, for all TLM calculations. Consistent with the results shown in Figure 4,

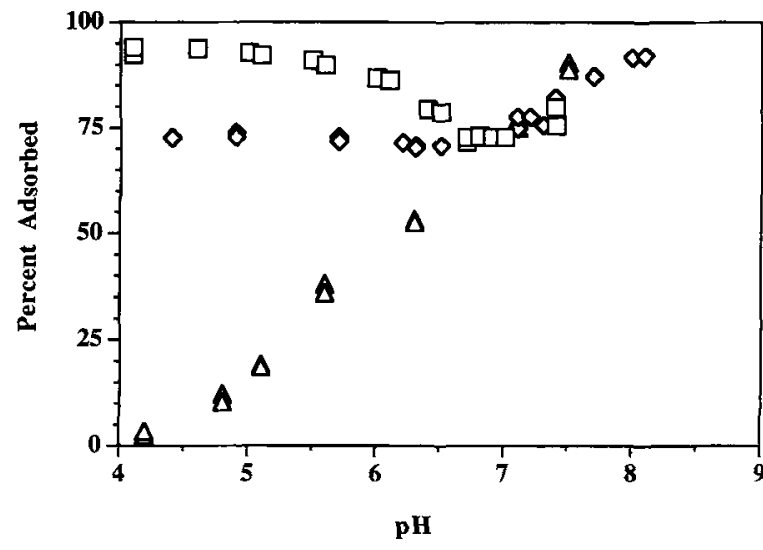

Figure 4. Combined adsorption results for uranyl binding to SWy-1. Suspension concentration was approximately 0.5 $\mathrm{g} \mathrm{L}^{-1}$; total uranium was $8.4 \times 10^{-6} \mathrm{~mol} \mathrm{~L}^{-1}$; the sodium perchlorate electrolyte concentration was varied: $0.001 \mathrm{~mol}$ $\mathrm{L}^{-1}=$ squares, $0.01 \mathrm{~mol} \mathrm{~L}^{-1}=$ diamonds, $0.1 \mathrm{~mol} \mathrm{~L}^{-1}=$ triangles.

ion exchange to fixed-charge sites was hypothesized to dominate adsorption at low $\mathrm{pH}$, while adsorption to edge sites was speculated to be more important at higher $\mathrm{pH}$. Ion-exchange contributions to adsorption were evaluated first, then combined with edge-site complexation to construct a unified adsorption model.

Edge-site concentrations on SWy-1 (Table 2) were determined from TEM data and bulk composition using the method described in detail by Zachara and Smith (1994). In this method, the mean equivalent diameter of $0.48 \mu \mathrm{m}$, the bulk composition, and the edge-site density for montmorillonite calculated by White and Zelazny (1988) $\left[\mathrm{N}_{\mathrm{S}, \mathrm{T}}=6.39 \mu \mathrm{mol} \mathrm{m}^{-2}\right.$ and $\mathrm{N}_{\mathrm{S}, \mathrm{O}}=5.32 \mu \mathrm{mol} \mathrm{m}^{-2}$, where $\mathrm{N}_{\mathrm{S}, \mathrm{T}}$ is the number of tetrahedral ( $\mathrm{SiOH})$ sites and $\mathrm{N}_{\mathrm{S}, \mathrm{O}}$ the number of octahedral (AlOH) sites] were used to estimate the total number of edge sites on SWy-1 at $3.52 \times 10^{-5} \mathrm{~mol}$ $\mathrm{g}^{-1}$.

\section{Derivation of constants}

Reactions with fixed-charge sites. Exchange constants for $\mathrm{UO}_{2}{ }^{2+}$ and its monovalent hydrolysis species $\left[\mathrm{UO}_{2} \mathrm{OH}^{+}\right.$and $\left.\left(\mathrm{UO}_{2}\right)_{3}(\mathrm{OH})_{5}{ }^{+}\right]$were calculated using the equation of Fletcher and Sposito (1989):

$$
\mathrm{K}_{1}=\left[\mathrm{K}_{\mathrm{a}} \mathrm{K}_{2}{ }^{\mathrm{za}}\left(\mathrm{a}_{\mathrm{a}}{ }^{\mathrm{zb}} / \mathrm{a}_{\mathrm{b}}{ }^{\mathrm{za}}\right)\left(\mathrm{m}_{\mathrm{ax}}+\mathrm{m}_{\mathrm{bx}}\right)^{(\mathrm{zb}-\mathrm{Za})}\right]^{1 / \mathrm{zb}}
$$

which was modified to yield

$$
\mathrm{K}_{1}=\left[\mathrm{K}_{\mathrm{a}} \mathrm{K}_{2}^{\mathrm{Za}}\left(\mathrm{mX}^{-}\right)^{(\mathrm{zb}-\mathrm{Za})}\right]^{1 / 2 \mathrm{~b}}
$$

where $K_{1}$ describes the half-reaction equilibrium constant $\left(\mathrm{mol} \mathrm{L}^{-1}\right)$ for interaction of a uranyl species of charge $Z_{a}$ with fixed-charge $X^{-}$sites (molal concentration), in competition with an ion of charge $Z_{b}$ whose binding is described by $K_{2}$. The value of $\log K_{2}$ was arbitrarily fixed at 13.8 for computation of $K_{1}$ values. 


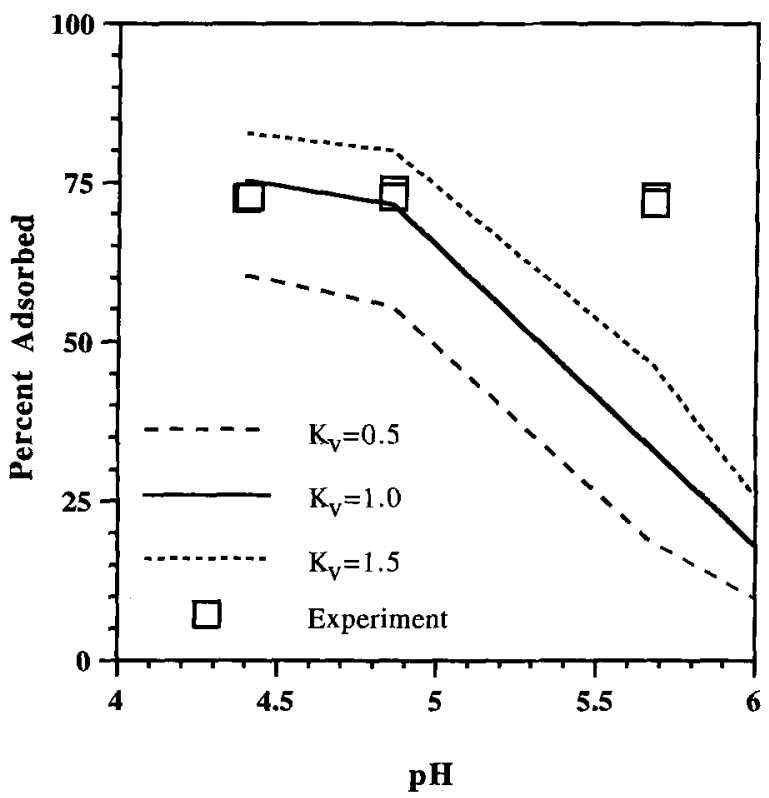

Figure 5. The effect of different values for the cation exchange selectivity constant $\left(\mathrm{K}_{\mathrm{v}}\right)$ on calculated uptake of uranyl by fixed-charge exchange sites. A non-selective constant $\left(\mathrm{K}_{\mathrm{v}}\right.$ $=1$ ) best reproduced the experimental results at $\mathrm{pH}<5$.

The constant $\mathrm{K}_{\mathrm{a}}$ is equivalent to the Vanselow selectivity coefficient, $K_{v}$, when the ratio of surface activity coefficients $\left(a_{a}\right.$ and $\left.a_{b}\right)$ is unity. Because the total $X$ concentration is approximately 500 times that of total uranyl, $\mathrm{mX}$ is an appropriate approximation of $\left(\mathrm{m}_{\mathrm{ax}}+\mathrm{m}_{\mathrm{bx}}\right)$, the summed molal concentrations of $\mathrm{X}^{-}$ site complexes derived from ions of different charge; $m X_{\text {Total }}$ was not significantly changed by proportionation of $\mathrm{X}^{-}$sites between complexes with univalent and divalent ions. In our computations, nonpreference exchange $\left(\mathrm{K}_{\mathrm{v}}=\mathrm{K}_{\mathrm{a}}=1.0\right)$ was assumed between $\mathrm{Na}$ and all of the uranyl species. The validity of this assumption was evaluated by comparing calculated and experimental results $\left(\mathrm{NaClO}_{4}=0.01 \mathrm{~mol} \mathrm{~L}^{-1}\right)$ using $\mathrm{K}_{\mathrm{v}}$ values of $0.5,1.0$, and 1.5 (Figure 5). Nonpreference exchange was found to most closely approximate low$\mathrm{pH}$ results for experiments at intermediate ionic strength. Although nonpreference exchange was used as an approximation of uranyl interaction with fixedcharge sites at all ionic strengths, exchange selectivity showed a small dependence on ionic strength. Experimental results were matched more closely using a slight preference for $\mathrm{Na}^{+}$at lower ionic strength $(0.001 \mathrm{M}$ $\mathrm{Na}$ ) and a slight preference for $\mathrm{UO}_{2}{ }^{2+}$ at higher ionic strength (0.1 M Na).

Reactions to edge sites. Gibbsite and silica surface sites were considered as analogues of the smectite edge. For gibbsite, acidity constants were fit to gibbsite acid-base titration data, then uranyl adsorption constants were fit to uranyl adsorption edges. Published acidity constants were used for the silica surface in fitting uranyl adsorption constants to silica/uranyl adsorption edges. The use of gibbsite as an analogue to smectite edge sites $(\mathrm{AlOH})$ formed by octahedrally coordinated aluminum atoms is complicated by differences in surface chemistry and morphology. Gibbsite consists of octahedrally coordinated aluminum, but its surface is populated by doubly coordinated hydroxyl groups on the basal plane as well as singly coordinated groups on the crystal edge. The doubly coordinated hydroxyl groups are less reactive than edge groups, however, and have been treated as nonreactive sites with respect to proton uptake (Hiemstra et al 1987). In addition, the edge structure of gibbsite is not identical to that of the octahedral layer in smectites. Gibbsite edges are composed of singly coordinated hydroxyl groups, whereas the octahedral layer in smectites includes singly coordinated hydroxyls as well as bridging oxygens between aluminum and silicon (White and Zelazny 1988). We have treated gibbsite as an analogue of the edge sites exposed at the surface of the smectite octahedral layer by discounting the reactivity of doubly coordinated hydroxyl ions and by independently estimating the concentration of sites at smectite and gibbsite edges.

Reactivity of AlOH sites. Initial modeling calculations indicated that the ability to simulate uranyl adsorption to smectite at high ionic strength and $\mathrm{pH}$ was dependent on the ionization and electrolyte complexation constants used for the AlOH surface. The surface chemistry of gibbsite is difficult to define uniquely because of uncertainty regarding edge and basal site concentrations and reactivity and because of complications arising from Al dissolution. Accordingly, different sets of adsorption constants, site densities, and surface areas can provide equivalent fits to titration and adsorption data on gibbsite. We evaluated several selfconsistent sets of gibbsite surface parameters for their ability to describe uranyl adsorption to $\mathrm{SW}-1$.

Three sets of surface parameters were obtained for the gibbsite used in the uranyl adsorption studies; one from Wieland et al (1993), and two from the fitting of acid-base titration data (Figure 6a). In evaluating titration data, the consumption of titrant from the dissolution of gibbsite was accounted for by fitting an operational $\mathrm{K}_{\mathrm{sp}}$ for $\mathrm{Al}(\mathrm{OH})_{3}$ to $\mathrm{pH}$-dependent $\mathrm{Al}$ concentrations in gibbsite suspensions (Figure $6 \mathrm{~b}$ ). The $\mathrm{K}_{\mathrm{sp}}$ was used as a component within FITEQL to drive $\mathrm{H}^{+}$ consumption by dissolution and aqueous $\mathrm{Al}$ speciation reactions. The correction of titration data for dissolution of the solid had a small, but discernible, effect on fitted values for acidity constants. In the modeling, no distinction was made between basal plane $\mathrm{Al}_{2} \mathrm{OH}$ and $\mathrm{AlOH}$ edge sites. The site concentration, $[\mathrm{AlOH}]_{\mathrm{T}}$, acidity constants, and electrolyte complexation con- 
stants were derived by modeling in two ways, described below.

The first set of parameters was derived from the titration data by simultaneously optimizing $[\mathrm{AlOH}]_{\mathrm{T}}$,

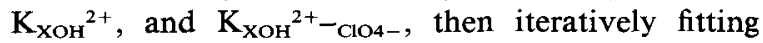
$\mathrm{K}_{\mathrm{XOH}}{ }^{-}$and $\mathrm{K}_{\mathrm{XOH}}{ }^{-}{ }^{-\mathrm{Na}^{+}}$. This procedure yielded a site concentration of $33.8 \mu \mathrm{mol} \mathrm{g}^{-1}$ and a $\log \mathrm{K}_{\mathrm{al}}\left(\mathrm{AlOH}_{2}{ }^{+}\right.$ $=\mathrm{AlOH}+\mathrm{H}^{+}$) of 12.3 (Model 1 calculations, Table 4). Our $\log K_{a 1}$ value was higher and our site concentration was lower than the single- $\mathrm{pK}_{\mathrm{a}}$ result of Hiemstra et al $(1987 ; \mathrm{pzc}=10$, no correction for $\mathrm{Al}$ dissolution, with $54.2 \mu \mathrm{mol}$ sites $\mathrm{g}^{-1}$ ).

The number of fitting parameters was reduced to three to arrive at a second set of parameters, by assuming that the intrinsic ion-pair formation constants for the electrolyte species $\mathrm{AlOH}_{2}{ }^{+}-\mathrm{ClO}_{4}{ }^{-}$and $\mathrm{AlO}^{-}-$ $\mathrm{Na}^{+}$were equal and that and the $\Delta \mathrm{pK}_{\mathrm{a}}$ was 5 . The fitting parameters were then $[\mathrm{AlOH}]_{\mathrm{T}}, \mathrm{K}_{\mathrm{al}}$, and the combined electrolyte binding constant. The fitted site concentration was $23.9 \mu \mathrm{mol}$ sites $\mathrm{g}^{-1}$, with a $\log \mathrm{K}_{\mathrm{al}}$ of 7.87 (Model 2 calculations, Table 4). The site concentration was lower than that for Model 1 and the first acidity constant $\left(\mathrm{K}_{\mathrm{al}}\right)$ was close to the value (7.6) from Wieland et al (1993; Model 3 calculations, Table 4); Wieland et al (1993) assumed a higher site concentration for their gibbsite $\left(74.5 \mu \mathrm{mol} \mathrm{g}^{-1}\right)$.

Reactivity of SiOH sites. The ionization and electrolyte complexation constants used here (Table 1) were taken from Zachara and Smith (1994), refitted from the data of Riese (1982) for experiments conducted on $\alpha-\mathrm{SiO}_{2}$ in $\mathrm{NaNO}_{3}$ electrolyte. Zachara and Smith (1994) described the adsorption of $\mathrm{Cd}^{2+}$ to $\mathrm{SiOH}$ edge sites on smectites, whereas Riese (1982) derived silica surface constants to model the adsorption of radium and thorium on quartz.

Uranyl adsorption to gibbsite and silica. The solution species $\mathrm{UO}_{2}{ }^{2+}, \mathrm{UO}_{2} \mathrm{OH}^{+}$, and $\left(\mathrm{UO}_{2}\right)_{3}(\mathrm{OH})_{5}{ }^{+}$, which are predominant over the experimental $\mathrm{pH}$ range (Figure 1), were considered when fitting adsorption constants to silica and gibbsite. Surface reactions between these species and surface sites leading to inner-sphere surface complexes were considered singly, in pairs, and altogether for their ability to describe the adsorption data. First, adsorption constants were fit individually for the three solution species on gibbsite and silica using the high-solids adsorption data. Simulative modeling of the low-sorbent suspensions was then attempted, but each of the calculations with only a single adsorbing species either overpredicted or underpredicted actual uranyl adsorption. Iterative fitting of constants between the two suspension concentrations was then attempted for pairs of aqueous species; constants for $\mathrm{UO}_{2} \mathrm{OH}^{+}$with either of the other species could not simultaneously predict uranyl adsorption in both suspensions. However, for both adsorbents, uptake of ura-
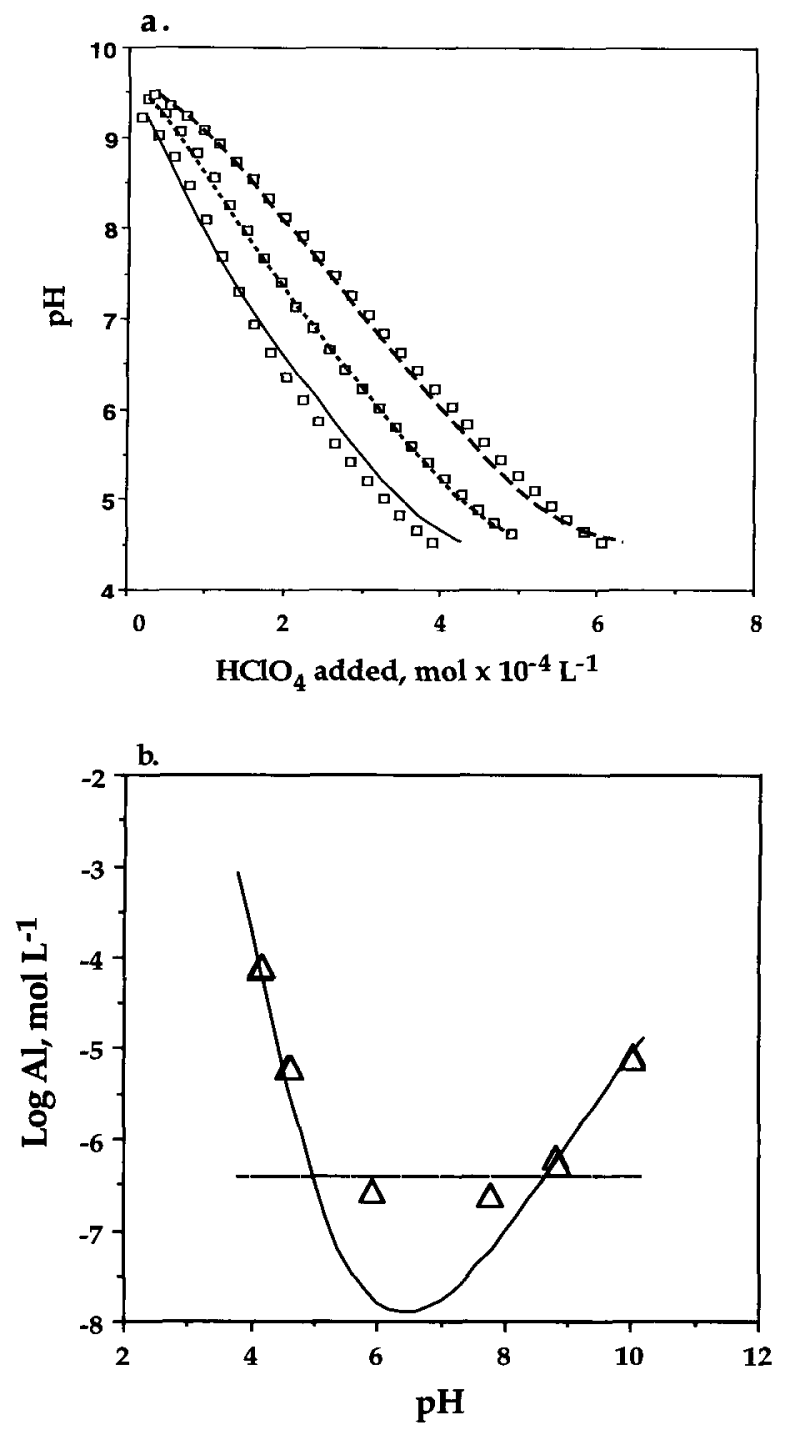

Figure 6. Results of acid/base titration of gibbsite at three ionic strengths $\left(0.001,0.01\right.$, and $0.1 \mathrm{~mol} \mathrm{~L}^{-1} \mathrm{NaClO}_{4}$. (a) Lines indicate data simulation where surface acidity constants, surface area, and electrolyte complexation constants were fit independently. (b) Aluminum dissolution observed at each experimental $\mathrm{pH}$, with the conditional $\mathrm{K}_{\mathrm{sp}}$ fit to experimental data (solid line); and the effective detection limit for dissolved aluminum (dashed line).

nyl could be well-described using $\mathrm{UO}_{2}{ }^{2+}$ and $\left(\mathrm{UO}_{2}\right)_{3}(\mathrm{OH})_{5}{ }^{+}$as adsorbing species (Figure 3). Addition of a $\mathrm{UO}_{2} \mathrm{OH}^{+}$surface complex, to form a threesorbate model, did not markedly change constants for the other species or significantly improve fits to or simulations of the experimental data.

The shift in adsorption to higher $\mathrm{pH}$ as the sorbent concentration decreased was accompanied by a reversal in the relative importance of each adsorbing species. Comparison of contributions to total adsorption (Model 1) at suspensions of $5.74 \mathrm{~g} \mathrm{~L}^{-1}$ gibbsite (Figure 3a) 
Table 4. Gibbsite constants used in fitting uranyl adsorption constants $\mathrm{K}_{\mathrm{UO}_{2^{2+}}}$ and $\mathrm{K}_{\left(\mathrm{UO}_{2)(O H) s^{+}}\right.}$Model 3 constants (other than uranyl adsorption constants) from Wieland et al (1993).

\begin{tabular}{|c|c|c|c|c|c|c|c|}
\hline & \multirow{2}{*}{$\underset{\mu \mathrm{mol} \mathbf{g}^{-1}}{\text { Sits }}$} & \multicolumn{6}{|c|}{ Log } \\
\hline & & $\mathrm{K}_{\mathrm{e} 1}$ & $K_{-2}$ & $\overline{K_{\mathbf{s}}}$ & $\mathrm{K}_{\mathrm{c}}+$ & $\mathrm{K}_{\mathrm{UO}_{2+}^{2+}}$ & $\mathbf{K}_{\left(\mathrm{UO}_{2}\right)_{3}(\mathrm{OH})_{3}+}$ \\
\hline Model 1 & 33.8 & 12.3 & -13.16 & 10.15 & -10.37 & 7.10 & -15.80 \\
\hline Model 2 & 23.9 & 7.87 & -12.87 & 10.38 & --10.36 & 6.25 & -15.80 \\
\hline Model 3 & 74.5 & 7.6 & -10.6 & 10.7 & -7.3 & 4.50 & -15.70 \\
\hline
\end{tabular}

$\mathrm{K}_{\mathrm{a} 1}\left(\mathrm{AlOH}+\mathrm{H}^{+}=\mathrm{AlOH}_{2}^{+}\right)$.

$\mathrm{K}_{\mathrm{a} 2}\left(\mathrm{AlOH}=\mathrm{AlO}^{-}+\mathrm{H}^{+}\right)$.

$\mathrm{K}_{\mathrm{a}^{-}}\left(\mathrm{AlOH}_{2}^{+}+\mathrm{ClO}_{4}^{-}=\mathrm{AlOH}_{2}^{+}-\mathrm{ClO}^{-}\right)$.

$\mathrm{K}_{\mathrm{c}}+\left(\mathrm{AlOH}+\mathrm{Na}^{+}=\mathrm{AlO}^{-}-\mathrm{Na}^{+}+\mathrm{H}^{+}\right)$.

$\mathrm{K}_{\mathrm{UO}_{2}}{ }^{2+}\left(\mathrm{AlOH}+\mathrm{UO}_{2}{ }^{2+}=\mathrm{AlO} \cdot \mathrm{UO}_{2}{ }^{+}+\mathrm{H}^{+}\right)$.

$\mathrm{K}_{(\mathrm{UO})_{3}(\mathrm{OH})_{5}}+\left[\mathrm{AlOH}+\left(\mathrm{UO}_{2}\right)_{3}(\mathrm{OH})_{5}{ }^{+}=\mathrm{AlO} \cdot\left(\mathrm{UO}_{2}\right)_{3}(\mathrm{OH})_{5}+\mathrm{H}^{+}\right]$.

and $0.55 \mathrm{~g} \mathrm{~L}^{-1}$ gibbsite (Figure 3b), for example, showed a computed predominance of the $\mathrm{UO}_{2}{ }^{2+}$ surface complex in the higher-mass gibbsite suspension, and predominance of the $\left(\mathrm{UO}_{2}\right)_{3}(\mathrm{OH})_{5}{ }^{+}$surface complex in the lower-mass gibbsite suspension. The relative importance of the two adsorbing species was dependent, in part, on aqueous uranyl speciation. At constant $\mathrm{pH}$, as the suspension concentration of gibbsite decreased, the fractional abundance of the polymeric aqueous species $\left(\mathrm{UO}_{2}\right)_{3}(\mathrm{OH})_{5}{ }^{+}$increased. At $\mathrm{pH} 5.7$, for example, aqueous $\left(\mathrm{UO}_{2}\right)_{3}(\mathrm{OH})_{5}{ }^{+}$was $1 \%$ of dissolved species at $5.74 \mathrm{~g}$ gibbsite $\mathrm{L}^{-1}$, and $17 \%$ at $0.55 \mathrm{~g}$ gibbsite $\mathrm{L}^{-1}$. The relationship of aqueous speciation to surface speciation for gibbsite was also observed for silica (Figure $3 c, d)$.

Uranyl adsorption constants (Table 4) were determined for each set of surface parameters on gibbsite (Models 1, 2, and 3). Equivalent descriptions of experimental data were obtained using each set of surface parameters (Figure $7 ; 5.74 \mathrm{~g} \mathrm{~L}^{-1}$ gibbsite). The effect of ionic strength on model results was evaluated by simulative calculations using fitted adsorption constants for Models 1, 2, and 3, in all of which the concentration of $\mathrm{NaClO}_{4}$ was reduced from 0.1 to 0.001 $\mathrm{mol} \mathrm{L}{ }^{-1}$. The results of these calculations are indicated as dashed lines in Figure 7. For Models 1 and 2, the
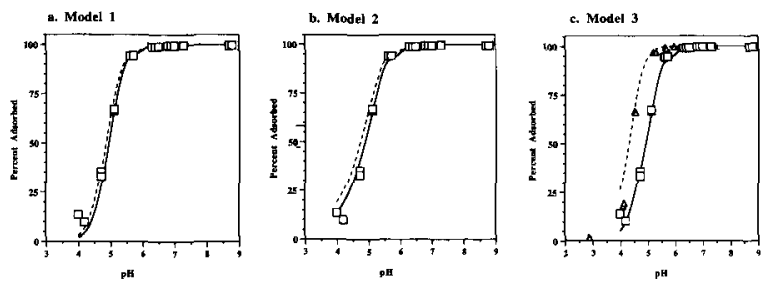

Figure 7. Experimental and calculated results of uranyl adsorption to gibbsite, $5.74 \mathrm{~g} \mathrm{~L}^{-1}$. Results for each model are shown with calculations at $\mathrm{NaClO}_{4}$ concentrations of $0.1 \mathrm{~mol}$ $\mathrm{L}^{-1}$ (lines) and $0.001 \mathrm{~mol} \mathrm{~L}^{-1}$ (dashes). Also shown for comparison with Model 3 calculations are experimental results of adsorption at two ionic strengths (squares $=0.1 \mathrm{~mol} \mathrm{~L}^{-1}$, triangles $=0.001 \mathrm{~mol} \mathrm{~L}^{-1}$ ). effect of ionic strength was minimal (Figure $7 a, b$ ), as shown previously for the inner-sphere complex formalism using the TLM (Hayes and Leckie 1987). Calculations using Model 3, however, showed a significant increase in adsorption at lower ionic strength (Figure $7 c)$. This increased adsorption resulted directly from the strength of the electrolyte anion surface complex in this model, which led to competition between the electrolyte anion $\left(\mathrm{ClO}_{4}^{-}\right)$and uranyl for surface sites at higher $\mathrm{pH}$. Regardless of the chemical reality of this strong electrolyte ion surface complex, comparison with experimental data collected at a $\mathrm{NaClO}_{4}$ concentration of $0.001 \mathrm{~mol} \mathrm{~L}^{-1}$ (Figure 7c) suggested that Model 3 most closely approximated the gibbsite surface properties.

\section{$S W y-1$ adsorption simulation}

No adjustable parameters were used in simulating experimental results for uranyl adsorption to $S W y-1$ (Figure 8). The estimation of exchange site and edge site concentrations on $\mathrm{SWy}-1$, from CEC measurements and clay-platelet diameters, resulted in good model approximations of experimental data using Model 1. Uranyl adsorption could be explained by the formation of surface complexes with fixed-charge $\left(\mathrm{UO}_{2} \mathrm{X}_{2}\right)$, aluminol $\left(\mathrm{AlO} \cdot \mathrm{UO}_{2}{ }^{+}\right)$, and silanol $\left[\mathrm{SiO}\left(\mathrm{UO}_{2}\right)_{3}(\mathrm{OH})^{+}\right]$sites. These complexes were consistent with, but did not correspond closely to, the changes in aqueous uranyl speciation; e.g., the surface complex $\mathrm{AlO} \cdot \mathrm{UO}_{2}{ }^{+}$persisted above the $\mathrm{pH}$ where $\mathrm{UO}_{2}{ }^{2+}$ predominated. Although a hydrolyzed surface species might be expected under conditions favoring hydrolysis in the aqueous phase, adsorbed species distinct from coexistent aqueous species may exist. Uranyl adsorbed to montmorillonite surfaces in particular has yielded spectroscopic evidence for lesshydrolyzed species at the mineral surface (ChisholmBrause et al 1994). The relatively small number of significant surface complexes modelled here is also supported by spectroscopic evidence; X-ray absorption spectroscopy (Chisholm-Brause et al 1994) and optical spectroscopy (Morris et al 1994) have both shown the 
existence of three predominant uranyl species on the fixed-charge and amphoteric aluminol and silanol edge sites of montmorillonite. Dent et al (1992) detected uranyl bound to fixed-charge sites on the SWy-1 surface at pH less than 5 .

TEM measurements, which obviated the need to use edge site concentrations as fitting parameters, yielded edge site concentrations that were different from fitted values obtained by other researchers. In a recent model of $\mathrm{Cu}^{2+}$ adsorption to SWy-1, Stadler and Schindler (1993) fitted edge-site concentrations to acid-base titration data because the binding of protons by individual surface sites could not be resolved experimentally. The AlOH concentrations of Stadler and Schindler (1993) were approximately three and one-half times the value obtained here, and the ratio of concentrations (AlOH: $\mathrm{SiOH}$ ) was 1.68 , twice the theoretical ratio (0.83; White and Zelazny 1988); an independent determination of site concentrations may have produced different results for acidity constants and $\mathrm{Cu}^{2+}$ binding constants.

Adsorption to exchange sites, treated identically in all three models, was affected by aqueous uranyl speciation (Figure 1) and the Na concentration in the electrolyte, as illustrated by Model 1 results (Figure 8). As $\mathrm{pH}$ increased at low $\mathrm{Na}$ concentration, fixed-charge uranyl complexes declined rapidly in concentration as $\mathrm{UO}_{2}{ }^{2+}$ was replaced in solution by monovalent species, and more abundant $\mathrm{Na}^{+}$successfully competed for fixed-charge sites. As $\mathrm{Na}$ concentration increased, the effect of aqueous uranyl speciation and competition was increased as $\mathrm{Na}^{+}$displaced uranyl through nonpreference exchange, even where $\mathrm{UO}_{2}{ }^{2+}$ was the dominant aqueous species.

Three issues warrant discussion in relation to the edge-site model calculations presented in Figure $8: 1$ ) the application of different model assumptions to simulations of experimental data; 2) the potential effects of edge site saturation and site coverage on model results; and 3) the effects of ionic strength on model and experimental results.

Model 1 and 2 calculations of adsorption to SWy-1 had differences that resulted from the way in which gibbsite titration data were modeled (Table 4). Gibbsite surface constants used to derive the uranyl adsorption constants for Model 1 included a relatively low $[\mathrm{AlOH}]_{\mathrm{T}}$ (18.76 $\mu \mathrm{mol}$ sites $\mathrm{L}^{-1}$ at gibbsite $\left.=0.555 \mathrm{~g} \mathrm{~L}^{-1}\right)$, and a high $\mathrm{K}_{\mathrm{a} 1}\left(\log \mathrm{K}_{\mathrm{a} 1}=12.3\right)$, resulting in a high value of the binding constant for $\mathrm{AlO}^{-\mathrm{UO}_{2}}{ }^{+}$. In applying Model 1 to SWy-1 data, the gibbsite surface acidity, electrolyte adsorption, and uranyl adsorption constants were used, but the $\mathrm{AlOH}$ site concentration $(9.9 \mu \mathrm{mol}$ sites $\mathrm{L}^{-1}$ ) was determined by calculations on TEM measurements of SWy-1 particle size. Although the value for the $\mathrm{AlO} \cdot \mathrm{UO}_{2}{ }^{+}$adsorption constant was the highest of the three models $(\log K=7.10)$, the high acidity constants specified a smectite edge that was
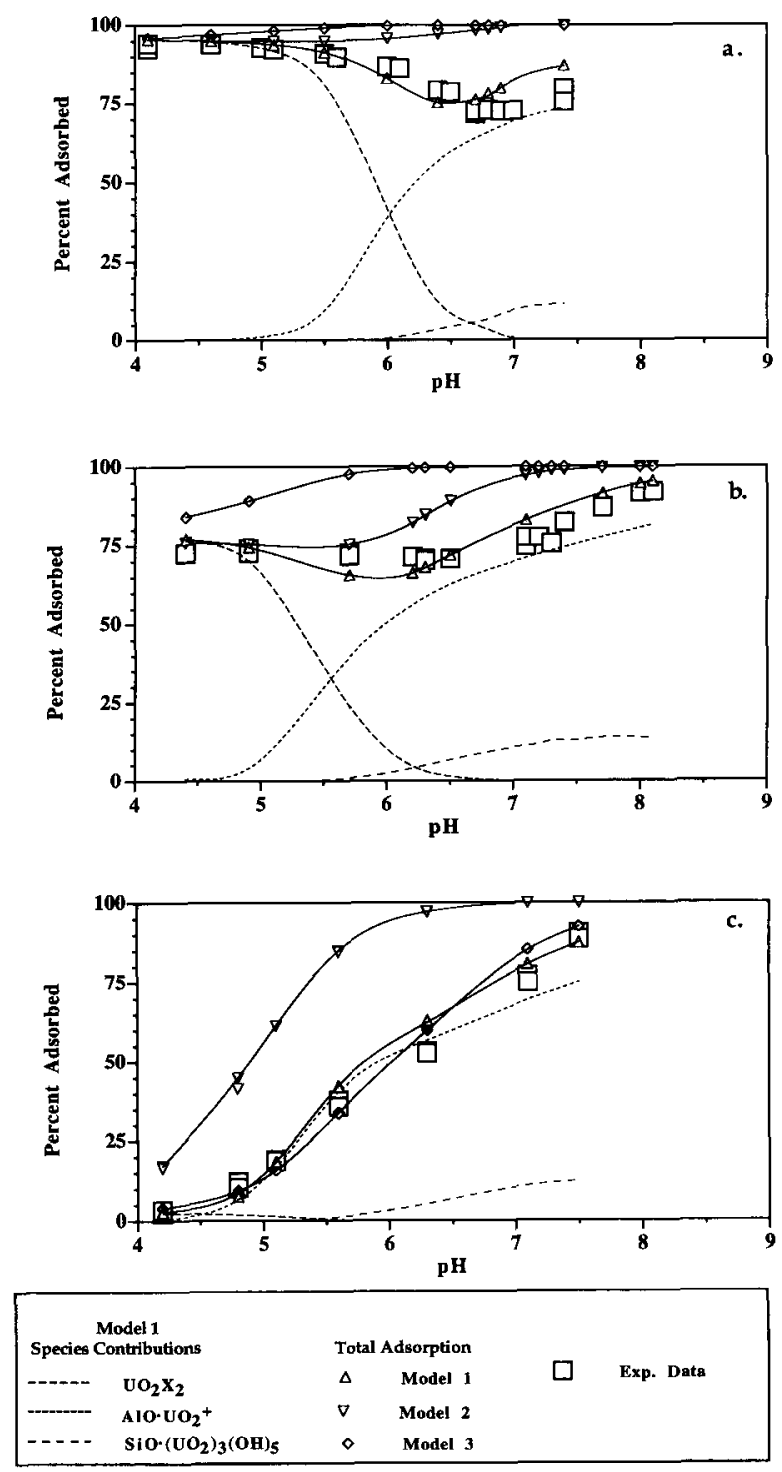

Figure 8. Model results for uranyl/SWy-1 interaction. Total predicted uptakes for constants derived by three methods are indicated (see text). Contributions to adsorption from $\mathrm{UO}_{2} \mathrm{X}_{2}$, $\mathrm{AlO} \cdot \mathrm{UO}_{2}{ }^{+}$, and $\mathrm{SiO}\left(\mathrm{UO}_{2}\right)_{3}(\mathrm{OH})_{5}$ are shown for the calculations that best predicted adsorption at all three ionic strengths (Model 1, see text).

positively charged throughout the experimental range in $\mathrm{pH}$. Model 1 results simulated the SWy-1 experimental data best at all three ionic strengths. Gibbsite surface constants used to derive uranyl binding constants for Model 2 included still lower $[\mathrm{AlOH}]_{\mathrm{T}}(13.27$ $\mu \mathrm{mol}$ sites $\mathrm{L}^{-1}$ at gibbsite $=0.555 \mathrm{~g} \mathrm{~L}^{-1}$ ), and a relatively low value for $\mathrm{K}_{\mathrm{a} 1}\left(\log \mathrm{K}_{\mathrm{a} 1}=7.87\right)$; the resultant $\mathrm{AlO} \cdot \mathrm{UO}_{2}{ }^{+}$binding constant was approximately $0.9 \mathrm{log}$ units lower in value than the Model 1 constant. When Model 2 was applied to SWy-1 data, the combination of a $K_{a 1}$ that was more than $5 \log$ units lower than that 
for Model 1, and an $\mathrm{AlO} \cdot \mathrm{UO}_{2}{ }^{+}$binding constant that was still relatively high, resulted in overprediction of uranyl binding at all ionic strengths. The published gibbsite surface constants (Wieland et al 1993) resulted in a high $[\mathrm{AlOH}]_{\mathrm{T}}\left(41.34 \mu \mathrm{mol}\right.$ sites $\mathrm{L}^{-1}$ at gibbsite $=$ $0.555 \mathrm{~g} \mathrm{~L}^{-1}$ ) with surface acidity constants that were similar to those for Model 2; the resultant $\mathrm{AlO} \cdot \mathrm{UO}_{2}{ }^{+}$ binding constant was lower than the Model 2 value $(\log \mathrm{K}=4.50)$. When applied to $\mathrm{SWy}-1$ experimental data, Model 3 simulated uranyl adsorption well at a $\mathrm{Na}$ concentration of $0.1 \mathrm{~mol} \mathrm{~L}^{-1}$ (the gibbsite uranyl binding constants were fit at this ionic strength). At lower ionic strengths, the shift toward increased adsorption caused by the relatively high value of the anion-binding constant resulted in an overprediction of adsorption.

The relatively large $S W y-1$ clay-platelet size resulted in a low abundance of edge sites in proportion to fixedcharge sites, so the computed surface speciation of uranyl on edge sites was affected by site saturation. In Model 1 calculations, $70 \%$ of $\mathrm{AlOH}$ sites were occupied by $\mathrm{UO}_{2}{ }^{2+}$ at maximum adsorption. The reduced concentration of available $\mathrm{AlOH}$ sites in combination with the relative magnitude of $\mathrm{SiOH}$ and $\mathrm{AlOH}$ binding constants was computed to reduce the potential for formation of $\mathrm{AlO} \cdot\left(\mathrm{UO}_{2}\right)_{3}(\mathrm{OH})_{5}$. Strong binding of uranyl to $\mathrm{AlOH}$ sites $\left(\log \mathrm{K}_{\mathrm{AlO} \cdot \mathrm{UO}^{+}}{ }^{+}=7.1\right)$ suppressed the formation of $\mathrm{SiO} \cdot \mathrm{UO}_{2}+\left(\log \mathrm{K}_{\mathrm{SiO} \cdot \text { uo2 }}{ }^{+}=0.15\right)$. The complex $\mathrm{SiO} \cdot\left(\mathrm{UO}_{2}\right)_{3}(\mathrm{OH})_{5}{ }^{+}$was computed to form because the values for $\mathrm{K}_{\mathrm{AOO} \cdot(\mathrm{UO} 2)_{3}(\mathrm{OH})_{5}}{ }^{+}$and $\mathrm{K}_{\mathrm{SiO} \cdot(\mathrm{UO} 2)_{3}(\mathrm{OH})_{5}}{ }^{+}$ were similar $\left(10^{-16.8}\right.$ and $10^{-15.8}$, respectively), and the concentration of $\mathrm{AlOH}$ sites available to form $\mathrm{AlO}$. $\left(\mathrm{UO}_{2}\right)_{3}(\mathrm{OH})_{5}$ was reduced by formation of $\mathrm{AlO} \cdot \mathrm{UO}_{2}{ }^{+}$. $\mathrm{SiOH}$ sites, on the other hand, were ionized to $\mathrm{SiO}^{-}$ at alkaline $\mathrm{pH}$, and $\mathrm{SiOH}$ were not occupied by uranyl complexes.

Because the sorbing ions are relatively large, multiple site coverage was considered for its potential effect on adsorption. The diameter of the $\mathrm{UO}_{2}{ }^{2+}$ ion is approximately $0.58 \mathrm{~nm}$ (Aberg et al 1983). Based on considerations of crystal chemistry, the $\left(\mathrm{UO}_{2}\right)_{3}(\mathrm{OH})_{5}{ }^{+}$ion consists of three uranium atoms at the apices of an equilateral triangle with an average edge length of 0.381 $\mathrm{nm}$; each atom is surrounded by hydroxyls and waters of hydration with an interatomic U-O distance of 0.244 $\mathrm{nm}$ (Aberg 1978). The longest dimension presented by the $\left(\mathrm{UO}_{2}\right)_{3}(\mathrm{OH})_{5}{ }^{+}$ion is, therefore, approximately 0.869 $\mathrm{nm}$. An estimation of surface-site dimensions obtained by inverting the overall site density for smectites (approximately $6 \mu \mathrm{mol}$ sites $\mathrm{m}^{-2}$; White and Zelazny 1988) yields an area per site of $2.77 \times 10^{-19} \mathrm{~m}^{2}$, equivalent to a square with an edge length of $0.53 \mathrm{~nm}$. The $\left(\mathrm{UO}_{2}\right)_{3}(\mathrm{OH})_{5}{ }^{+}$ion, therefore, covers an area at the smectite surface that is potentially larger than that occupied by the complexing site. The effect of interference with adsorption to adjacent sites was evaluated by calculations in which three sites were removed from fur- ther interaction for each $\left(\mathrm{UO}_{2}\right)_{3}(\mathrm{OH})_{5}{ }^{+}$ion adsorbed to either $\mathrm{AlOH}$ or SiOH sites. The computed maximum reduction to overall adsorption was less than $2 \%$ at the highest $\mathrm{pH}$ modelled, indicating that the relative size of adsorbing ions did not significantly affect modelled results.

An unexpected computational result was the response of uranyl edge complexation at low $\mathrm{pH}$ and varying ionic strength for Model 1 . As ionic strength increased, the percentage adsorption of $\mathrm{UO}_{2}{ }^{2+}$ to $\mathrm{AlOH}$ sites was computed to increase; at $\mathrm{pH} 5.2$, the edge complex contribution increased from approximately $4 \%$ at $I=0.004$ to $17 \%$ at $I=0.1$. This increase resulted from aqueous uranyl speciation and changes in competitive adsorption by edge and exchange sites. As uranyl binding to exchange sites was inhibited with increasing $\mathrm{Na}$, the aqueous concentration of uranyl increased. Concentration and ionic-strength effects on speciation caused the fraction of $\mathrm{UO}_{2}{ }^{2+}$ in the aqueous phase to increase as well. At pH 5.2, for example, the percent of dissolved uranyl as $\mathrm{UO}_{2}{ }^{2+}$ increased from $54 \%$ to $62 \%$ as ionic strength changed from 0.004 to 0.1 . This increase led, by mass action, to a concomitant increase in $\mathrm{AlO} \cdot \mathrm{UO}_{2}{ }^{+}$.

\section{CONCLUSIONS}

The $\mathrm{pH}$ and ionic strength-variant system of uranyl on $S W y-1$ could be described as a composite of reactions between the sorbate and fixed-charge cation-exchange sites and variable-charge $\mathrm{SiOH}$ and $\mathrm{AlOH}$ edge sites. The relative concentrations of edge and basalplane surface (exchange) sites were fixed by solid-phase composition and morphology. The contribution to adsorption of the modelled sites could be modelled discretely if their concentrations were estimated independently. The use of the analogue components, silica and gibbsite, to predict uranyl edge complexation reactions was highly dependent on the reaction parameters selected for the aluminol site. For our application, the best suite of surface constants for the $\mathrm{AlOH}$ site involved a $\log K_{a 1}$ of 12.3 , specifying negligible development of neutral or negatively charged aluminol sites at the smectite edge. Whether the success of this particular suite of constants was fortuitous or indeed had mechanistic implications was not established. The high value for $K_{a 1}$, although derived from gibbsite titration data, may reflect conditions at the smectite edge that are distinct from the gibbsite surface, because uranyl adsorption to gibbsite was better modelled using surface acidity and electrolyte complexation constants with more conventional values.

Model calculations made without fitting parameters indicate the presence of three predominant species on the smectite surface: $\mathrm{UO}_{2}{ }^{2+}$ bound to exchange sites, $\mathrm{UO}_{2}{ }^{2+}$ bound to $\mathrm{AlOH}$ sites, and $\left(\mathrm{UO}_{2}\right)_{3}(\mathrm{OH})_{5}{ }^{+}$bound to $\mathrm{SiOH}$ sites. The least significant surface complex, $\mathrm{SiO} \cdot\left(\mathrm{UO}_{2}\right)_{3}(\mathrm{OH})_{5}$, contributed significantly to uranyl 
adsorption above a $\mathrm{pH}$ of 6 . The aqueous speciation of uranyl was a significant determinant of uranyl adsorption. The formation of monovalent aqueous uranyl species as $\mathrm{pH}$ increased caused desorption of uranyl from basal-plane sites in the presence of a more abundant monovalent electrolyte cation. Changes in uranyl speciation, e.g., the increased abundance of $\mathrm{UO}_{2}{ }^{2+}$ at low $\mathrm{pH}$ as ionic strength increased, caused uranyl adsorption to $\mathrm{AlOH}$ sites to increase slightly with increasing ionic strength, and increased abundance of $\left(\mathrm{UO}_{2}\right)_{3}(\mathrm{OH})_{5}{ }^{+}$at higher $\mathrm{pH}$ accounted in part for the formation of $\mathrm{SiO}\left(\mathrm{UO}_{2}\right)_{3}(\mathrm{OH})_{5}$. The concentration ratio of $\mathrm{UO}_{2}{ }^{2+}$ : $\left(\mathrm{UO}_{2}\right)_{3}(\mathrm{OH})_{5}{ }^{+}$at elevated $\mathrm{pH}$, combined with surface acidity and surface binding constants that caused a large fraction of $\mathrm{AlOH}$ sites to be occupied by $\mathrm{UO}_{2}{ }^{2+}$, gave rise to $\mathrm{SiO}\left(\mathrm{UO}_{2}\right)_{3}(\mathrm{OH})_{5}$ to the exclusion of $\mathrm{AlO} \cdot\left(\mathrm{UO}_{2}\right)_{3}(\mathrm{OH})_{5}$. These results differed from those for metals that did not have significant $\mathrm{pH}$ effects on speciation, such as $\mathrm{Cd}$, where only a single aqueous metal species was proportionated between surface sites (Zachara and Smith 1994).

\section{ACKNOWLEDGMENTS}

This research was supported by the Subsurface Science Program, Office of Health and Environmental Research, U.S. Department of Energy (DOE). It is a CoContaminant Chemistry contribution. The continued support of Dr. Frank Wobber is greatly appreciated. The authors thank Dr. S.Y. Lee and an anonymous reviewer for helpful comments and suggestions, and Dr. R.E. Farrell, Jr., for editorial review. Pacific Northwest Laboratory is operated for DOE by Battelle Memorial Institute under Contract DE-AC06-76RLO 1830 .

\section{REFERENCES}

Aberg, M. 1978. The crystal structure of hexaaqua-tri- $\mu$-tri- $\mu_{3}-$ oxo-triuranyl(VI) nitrate tetrahydrate, $\left[\left(\mathrm{OU}_{2}\right)_{3} \mathrm{O}(\mathrm{OH})_{3}\left(\mathrm{H}_{2} \mathrm{O}\right)_{6}\right]-$ $\mathrm{NO}_{3} \cdot 4 \mathrm{H}_{2} \mathrm{O}$. Acta Chemica Scandinavica 32: 101-107.

Aberg, M., D. Ferri, J. Glaser, and I. Grenthe. 1983. Structure of the hydrated dioxyuranium (VI) ion in aqueous solution. An X-ray diffraction and ${ }^{1} \mathrm{H}$ NMR study. Inorg. Chem. 22: 3986-3989.

Allard, B., U. Olofsson, B. Torstenfelt, and H. Kipatsi. 1983. Sorption behavior of actinides in well-defined oxidation states. $S K$ BF KBS Technical Report 1983-05-15. Chalmers University of Technology, Goteborg, Sweden.

Babcock, K. L., and R. K. Schultz. 1970. Isotopic and conventional determination of exchangeable sodium percentage of soil in relation to plant growth. Soil Sci. 109: 19-22.

Bonotto, D. M. 1989. The behavior of dissolved uranium in groundwaters of the Morro do Ferro thorium deposit, Brazil. J. Hydrology 107: 155-168.

Borovec, Z. 1981. The adsorption of uranyl species by fine clay. Chem. Geo, 32: 45-58.

Chisholm-Brause, C., S. D. Conradson, C. T. Buscher, P. G. Eller, and D. E. Morris. 1994. Speciation of sites on montmorillonite. Geochim. et Cosmichim. Acta 58: 3625-3631.

Davis, J. A., and J. O. Leckie. 1978. Surface ionization and complexation at the oxide/water interface II. Surface properties of amorphous iron oxyhydroxide and adsorption of metal ions. J. Colloid Interface Sci. 67: 90-107.
Dent, A. J., J. D. F. Ramsay, and S. W. Swanton. 1992. An EXAFS study of uranyl ion in solution and sorbed onto silica and montmorillonite clay colloids. J. Colloid Interface Sci. 150: 45-60.

Fiala, V. 1988. The significance of the clay minerals in the genesis of hydrothermal uranium deposits. Tenth Conference on Clay Mineralogy and Petrology, Ostrava (1986), 255-260.

Fletcher, P., and G. Sposito. 1989. The chemical modeling of clay/electrolyte interaction for montmorillonite. Clay Miner. 24: 375-391.

Giblin, A. M. 1980. The role of clay adsorption in genesis of uranium ores. Uranium in the Pine Creek Geosyncline. International Atomic Energy Agency, Vienna, Austria, 521529.

Grenthe, I. Chairman. 1992. Chemical Thermodynamics of Uranium. New York: North-Holland, 715 pp.

Hayes, K. F., and J. O. Leckie. 1987. Modeling ionic strength effects on cation adsorption at hydrous oxide/solution interfaces. J. Colloid Interface Sci. 115: 564-572.

Hiemstra, T., W. H. van Riemsdijk, and M. G. M. Bruggenwert. 1987. Proton adsorption mechanism at the gibbsite and aluminum oxide solid/solution interface. Netherlands J. Agricultural Sci. 35: 281-293.

Ho, C. H., and N. H. Miller. 1985. Effect of humic acid on uranium uptake by hematite particles. J. Colloid Interface Sci. 106: 281-288.

Hsi, C.-K. D., and D. Langmuir. 1985. Adsorption of uranyl onto ferric oxyhydroxides: Application of the surface complexation site-binding model. Geochim. Cosmochim. Acta 49: 1931-1941.

Lieser, K. H., S. Quandt-Klenk, and B. Thybusch. 1992. Sorption of uranyl ions on hydrous silicon dioxide. Radiochim. Acta 57: 45-50.

Maya, L. 1982. Sorbed uranium (VI) species on hydrous titania, zirconia, and silica gel. Radiochim. Acta 31: 147151.

Morin, K. A., J. A. Cherry, T. P. Lim, and A. J. Vivyurka. 1982. Contaminant migration in a sand aquifer near an inactive uranium tailings impoundment, Elliot Lake, Ontario. Canadian Geotechnical J. 19: 49-62.

Morin, K. A., and J. A. Cherry. 1988. Migration of acidic groundwater seepage from uranium-tailings impoundments, 3. Simulation of the conceptual model with application to seepage area A. J. Contaminant Hydrology 2: 323 342.

Morris, D. E., C. J. Chisholm-Brause, M. E. Barr, S. D. Conradson, and P. G. Eller. 1994. Spectroscopic evidence for discrete multiple sorption sites for $\mathrm{UO}_{2}{ }^{2+}$ species on a reference smectite. Geochim. et Cosmochim. Acta 58: 36133623.

Newman, A. C. D., and G. Brown. 1987. The chemical constitution of clays. In Chemistry of Clays and Clay Minerals, A. C. D. Newman, ed. Mineralogical Society Monograph No. 6. New York: John Wiley \& Sons, 1-128.

Newman, A. C. D. 1987 . The interaction of water with clay mineral surfaces. In Chemistry of Clays and Clay Minerals, A. C. D. Newman, ed. Mineralogical Society Monograph No. 6. New York: John Wiley \& Sons, 237-274.

Payne, T. E., and T. D. Waite. 1991. Surface complexation modeling of uranium sorption data obtained by isotope exchange techniques. Radiochim. Acta 52: 487-493.

Riese, A. C. 1982. Adsorption of radium and thorium on quartz and kaolinite: A comparison of solution/surface equilibrium models. Ph.D. dissertation, Colorado School of Mines.

Riley, R. G., J. M. Zachara, and F. J. Wobber. 1992. Chemical Contaminants on DOE Lands and Selection of Contaminant Mixtures for Subsurface Science Research. Report 
DOE/ER-0547T. U.S. Department of Energy, Office of Energy Research, Washington, D.C.

Schindler, P. W., P. Liechti, and J. C. Westall. 1987. Adsorption of copper, cadmium, and lead from aqueous solution to the kaolinite/water interface. Netherlands J. Agricultural Sci. 35: 219-230.

Sposito, G. 1984. The Surface Chemistry of Soils. New York: Oxford University Press, $234 \mathrm{pp}$.

Sposito, G. 1989. The Chemistry of Soils. New York: Oxford University Press, 277 pp.

Sposito, G., K. M. Holtzclaw, C. T. Johnston, and C. S. LeVesque-Madore. 1981. Thermodynamics of sodiumcopper exchange on Wyoming bentonite at $298^{\circ} \mathrm{K}$. Soil Sci. Soc. Am. J. 45: 1079-1084.

Stadler, M., and P. W. Schindler. 1993. Modeling of $\mathrm{H}^{+}$ and $\mathrm{Cu}^{2+}$ adsorption on calcium-montmorillonite. Clays \& Clay Miner. 41: 288-296.

Thomson, B. M., P. A. Longmire, and D. G. Brookins. 1986. Geochemical constraints on underground disposal of uranium mill tailings. Applied Geochem. 1: 335-343.

Tripathi, V.J. 1984. Uranium (VI) transport modeling: Geochemical data and submodels. Ph.D. dissertation, Stanford University.

Tsunashima, A., G. W. Brindley, and M. Bastovanov. 1981. Adsorption of uranium from solutions by montmorillonite; Compositions and properties of uranyl montmorillonites. Clays \& Clay Miner. 29: 10-16.

Westall, J. 1982a. FITEQL. A computer program for deter- mination of equilibrium constants from experimental data. Version 1.2. Report 82-01, Department of Chemistry, Oregon State University, Corvallis, Oregon.

Westall, J. 1982b. FITEQL. A computer program for determination of equilibrium constants from experimental data. Version 2.0. Report 82-02, Department of Chemistry, Oregon State University, Corvallis, Oregon.

Westall, J.C., and A.L., Herbellien. (1993) FITEQL. A computer program for determination of equilibrium constants from experimental data. Version 3.1. Report 94-01, Department of Chemistry, Oregon State University, Corvallis, Oregon.

White, G. N., and L. W. Zelazny. 1988. Analysis and implications of the edge structure of dioctahedral phyllosilicates. Clays \& Clay Miner. 36: 141-146.

Wieland, E., M. Kohler, and J. O. Leckie. 1995. Adsorption of neptunium $[\mathrm{Np}(\mathrm{V})]$ on mineral surfaces: Modeling of surface complexation. Geochim. Cosmochim. Acta (in press.)

Zachara, J. M., and S. C. Smith. 1994. Edge site contributions to $\mathrm{Cd}$ sorption on specimen and soil-derived smectite in $\mathrm{Na}^{+}$and $\mathrm{Ca}^{2+}$ electrolytes. Soil Sci. Soc. Am. J. (in press).

Zachara, J. M., S. C. Smith, J. P. McKinley, and C. T. Resch. 1993. Cadmium sorption on specimen and soil smectites in $\mathrm{Na}^{+}, \mathrm{Ca}^{2+}$, and $\mathrm{Na}^{+} / \mathrm{Ca}^{2+}$ electrolytes. Soil Sci. Soc. Am. J. 57: 1491-1501.

(Received 12 July 1994; accepted 17 February 1995; ms. 2538) 